
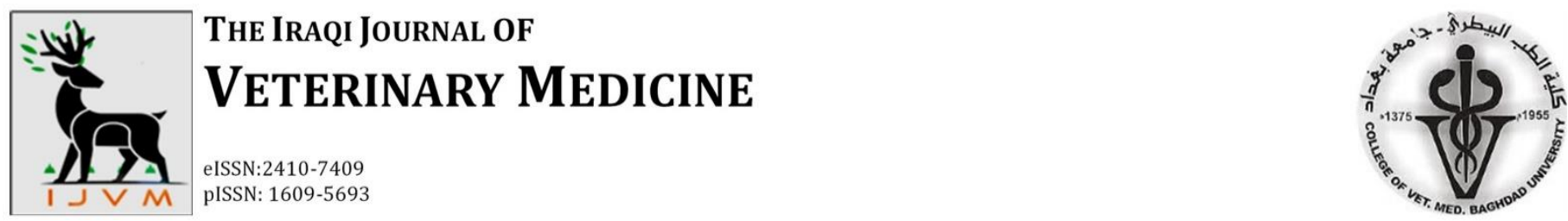

OPEN ACCESS

\title{
Serological and Molecular Phylogenetic Detection of Coxiella burnetii in Lactating Cows, Iraq
}

\author{
Hasanain A J Gharban* ${ }^{\circ}$, Afaf A Yousif \\ Department. of Internal and Preventive Veterinary Medicine, College of Veterinary Medicine, University \\ of Baghdad, Iraq
}

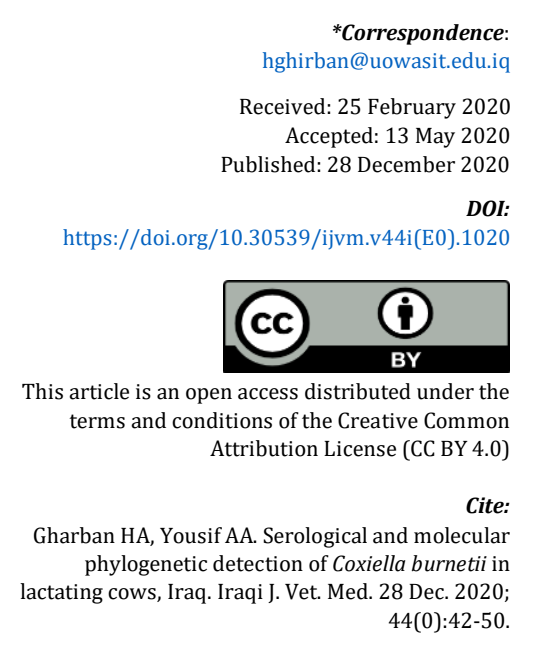

\begin{abstract}
$\begin{array}{llllllllllllllllllll}\text { A } & \text { B } & \mathbf{S} & \mathbf{T} & \mathbf{R} & \mathbf{A} & \mathbf{C} & \mathbf{T}\end{array}$
This study is carried out to investigate the prevalence of Coxiella burnetii (C. burnetii) infections in cattle using an enzyme-linked immunosorbent assay (ELISA) and polymerase chain reaction (PCR) assay targeting IS1111A transposase gene. A total of 130 lactating cows were randomly selected from different areas in Wasit province, Iraq and subjected to blood and milk sampling during the period extended between November 2018 and May 2019. ELISA and PCR tests revealed that $16.15 \%$ and $10 \%$ of the animals studied were respectively positive. Significant correlations $(\mathrm{P}<0.05)$ were detected between the positive results and clinical data. Two positive PCR products were analyzed phylogenetically, named as $C$. burnetii IQ-No.5 and C. burnetii IQ-No.6; and then recorded in the National Center for Biotechnology Information (NCBI) under an accession numbers of MN473204.1 and MN473205.1. Comparative identity of the local strains with NCBI-BLAST strains/isolates revealed $97 \%$ similarity and $0.1-0.6 \%$ of total genetic mutations/changes. NCBI-BLAST Homology Sequence reported high significant identity $(\mathrm{P}<0.05)$ between the local, C. burnetii IQ-No.5 and C. burnetii IQ-No.6; strains and C. burnetii 3345937 (CP014354.1) Netherlands isolate at $99.10 \%$ and $99.06 \%$, respectively. The current study concluded that the percentage of infected cows with coxiellosis is relatively high, and Coxiella should be listed as abortive pathogen. Therefore, additional studies should be performed including different animals, samples, and regions.
\end{abstract}

\section{INTRODUCTION}

B ovine coxiellosis is a common zoonotic infection caused by Coxiella burnetii, an obligate intracellular gamma proteobacterial organism (1). The disease is worldwide distribution except New Zealand and Antarctica; however, the incidence rate appears to vary considerably throughout all countries (2). In recent years, changes in social-economical, environmental, and ecological factors may be in contributing of emergence a large number of human cases that are attributed mostly to livestock sheep, goats and cattle (3). In cattle, Coxiella burnetii ( $C$. burnetii) infection is commonly subclinical (asymptomatic) but it can result in reduced reproductive performance (4). 
Various quantities of bacteria can be shed by infected animals through different routes (5). Intra-herd infection dynamic of a dairy herd is mainly influenced by the heterogeneity of the shedding routes. One of the important uncertainties concerning dynamics of infection lies in the contributions of the different routes in transmitting $C$. burnetii between livestock herds (6). In pregnant cows, the outcomes of infection involve an abortion, weak offspring, stillbirth, and premature delivery (7). Airborne transmission of Coxiella is well documented phenomenon (8). For humans, inhalation of contaminated aerosols generated during parturition, and ingestion of raw milk/unpasteurized dairy products of infected cows consider as the principal sources of infection $(9,10)$. Hence, intensive cattle farming with high prevalence could become a concern for public health, and investigation of infection dynamics in cattle herds is essential in the emergence to control continuum (11).

For the diagnosis, there are many laboratory tools that available for detecting $C$. burnetii using many biological samples (12). Even though the direct detection of Coxiella is more useful in veterinary pathology, cultivating of this fastidious microorganism is difficult and restricts to reference centers as it requires biosafety-level 3 laboratories and relies on cell culture which is performed by expert technicians (13). Serological screening of humans and animals for the detection of the organism specific antibodies by enzyme-linked immunosorbent assay (ELISA) has been found to be more sensitive and easier to be performed (14). Using only this method is not sufficient to demonstrate the infection so additional testing focused on confirmation the presence of the organism or its DNA is necessary (15). The development of highly sensitive and specific molecular assays has prompted the routine use of polymerase chain reaction (PCR) based analysis to assess the health status of the herds towards many pathogens including $C$. burnetii and ensure the safety (16). Hence, this study aimed to use serological ELISA and molecular PCR in detecting $C$. burnetii in both serum and milk samples of lactating cow, and documentation some positive PCR strains in the National Centers for Biotechnology Information (GenBank-NCBI) for the first time in Iraq. This study also targeted to correlate their positivity associated with the clinical data of reproductive system.

\section{MATERIALS AND METHODS}

\section{Animals and Sample Collection}

The present study is approved and performed under the Council of College of Veterinary Medicine, and the authority of the Department of Internal and Preventive Veterinary Medicine, College of Veterinary Medicine, University of Baghdad.

A total of 130 lactating cows from many areas in Wasit province, and of different ages and breeds were subjected for this study during the period extended from November 2018 to May 2019. Under aseptic conditions, approximately $50 \mathrm{~mL}$ of milk was collected directly from udder quarters of each cow into a plastic container that was labeled, noted, and kept into a cooled icebox. Furthermore, $10 \mathrm{~mL}$ of jugular venous blood was drained by a disposable syringe into free-anticoagulant glass gel tube. At laboratory, blood samples were centrifuged ( $4000 \mathrm{rpm}, 5 \mathrm{~min}$ ), and sera were preserved in $1.5 \mathrm{~mL}$ labeled Eppendorf tubes. Both sera and milk tubes were frozen at $-20^{\circ} \mathrm{C}$ until be tested by ELISA and PCR, respectively. Case history data concerning to age, breed, tick infestation, and other animals' data at same herds/pasture, herd size, reproductive performance, and milk production were detected.

\section{Serology by Indirect ELISA}

Using a commercially available indirect ELISA (Sunlong Biotech, China) Kit, serum samples and buffer diluents were prepared and diluted. Following the manufacturer's instruction, a total $10 \mu \mathrm{L}$ of each serum sample from each sample was used for detecting specific IgG antibodies against Phase I and Phase II antigen of $C$. burnetii. After the final step of ELISA procedure and adding of Stop Solution, absorbance (OD) was measured at a wavelength of $450 \mathrm{~nm}$ using an ELISA microplate reader (BioTek, USA). Critical value (CUT OFF) was calculated as the following formula: CUT OFF $=$ Average value of Negative Control +0.15 . Sample is considered positive when OD value $\geq$ CUT OFF; and negative when OD value < CUT OFF.

\section{Molecular Conventional PCR Assay}

Using $200 \mu \mathrm{L}$ of each milk sample, DNAs were extracted following the Protocol A of G-spin ${ }^{\mathrm{TM}}$ Total DNA extraction (Intron, Biotechnology, South Korea) Kit. Concentration and purification of extracted DNAs were checked by Nanodrop spectrophotometer (Thermo-Scientific, UK) at an absorbance of A260/A280nm; and estimated as approximately as $6 \mu \mathrm{g}$ for concentration and 1.6-1.9 $\mathrm{nm}$ for purification.

For PCR amplification, one set of primers [(F: 5'-TAT GTA TCC ACC GTA GCC AGT C-3') and (R: 5'-CCC AAC AAC ACC TCC TTA TTC-3')] targeting IS1111A transposase gene was designed as previously described $(17,18)$, and provided by the Macrogen Company (South Korea). A ready AccuPower PCR-PreMix (Bioneer, South Korea) Kit was used to prepare the PCR-Master mix at a final volume of 20 $\mu \mathrm{L}(5 \mu \mathrm{L}$ DNA template, $1 \mu \mathrm{L}$ F-Primer, $1 \mu \mathrm{L}$ R-Primer, and $13 \mu \mathrm{L}$ free-nuclease water) for each sample. For PCR reaction and Thermal Cycler (Bio-Rad, USA) conditions were as follows: initial denaturation $\left(98^{\circ} \mathrm{C}, 30 \mathrm{sec}\right) 1$ cycle; denaturation $\left(98{ }^{\circ} \mathrm{C}, 7 \mathrm{sec}\right)$, annealing $\left(60^{\circ} \mathrm{C}, 20 \mathrm{sec}\right)$, extension $\left(72^{\circ} \mathrm{C}, 20 \mathrm{sec}\right) 30$ cycles, final extension $\left(72^{\circ} \mathrm{C}, 7\right.$ min) 1 cycle, and hold $\left(4^{\circ} \mathrm{C}\right.$, Forever). At 100 volt and 80 $\mathrm{mA}$ for 1 hour, $1.5 \%$ agarose gel-electrophoresis stained 
with ethidium bromide to analyze the PCR-products that were visualized under UV illuminator (Clinx Science, China). According to standard size of the band of Ladder Marker (100-1500 bp), the samples of PCR product were considered positives at an amplicon size of $687 \mathrm{bp}$.

To confirm local $C$. burnetii strains, two positive PCR products were sent for phylogenetic analysis at Macrogen Company (South Korea). Sequencing results were received by private mail were analyzed by the Multiple Sequence Alignment Program, and phylogenetic tree was constructed using of MEGA- 6 software; and homology identity between the local strains $C$. burnetti and GenBank-NCBI strains/isolates was detected.

\section{Statistical Analysis}

All collected data were documented and tabulated using the Microsoft Office Excel (version 2016) and analyzed statistically by IBM/SPSS (version 23). Chi-square $\left(x^{2}\right)$ test and one-way analysis of variance (ANOVA) were applied for the finding of ELISA and PCR, and for the risk factors, respectively. Differences were considered significant at $\mathrm{P}<0.05(19,20)$.

\section{RESULTS}

Of 130 tested sera using indirect ELISA, 21 (16.15\%) cows were positive to IgG antibodies against $C$. burnetii. Whilst the results of PCR assay showed that among 130 milk samples tested, $13(10 \%)$ samples were positive for IS1111A transposase gene (Table 1, Figure 1). Statistically, ELISA positivity was higher than that detected in PCR assay $(\mathrm{P}<0.05)$. In addition, ODs' levels of seropositive study cows were showed significant differences in their values (Figure 2).

Table 1. Total positive results of ELISA and PCR among 130 study cows

\begin{tabular}{cccc}
\hline \hline Test & Total No. & Positives & Negatives \\
\hline ELISA & 130 & $21(16.15 \%) *$ & 109 \\
PCR & 130 & $13(10 \%)$ & 117 \\
\hline *Significant $(\mathrm{P}<0.05)$ & &
\end{tabular}

*Significant $(\mathrm{P}<0.05)$

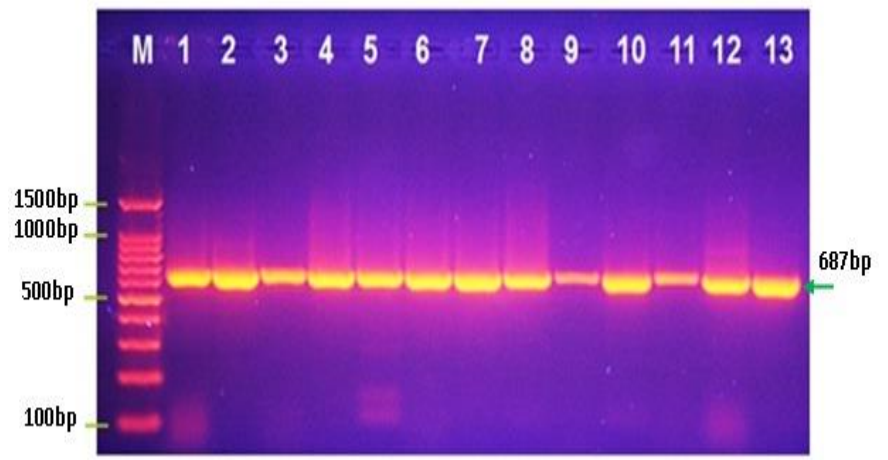

Figure 1. Agarose-gel electrophoresis at 100 Volt and $80 \mathrm{~mA}$ for 1 hour

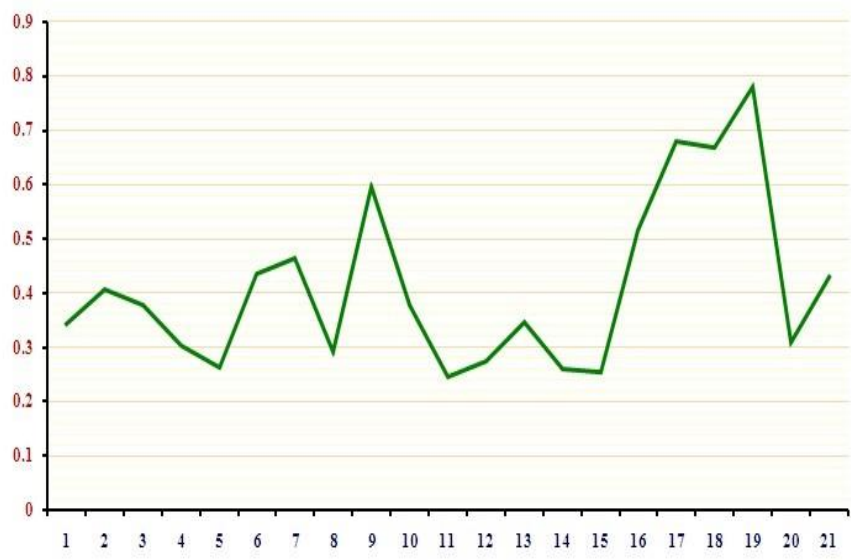

Figure 2. ODs' levels of seropositive study cows

Association between the positive results of ELISA and PCR was showed to be 11 (8.46\%) of cows were positives by both assays in comparison with 10 (7.69\%) were positive by ELISA only and $2(1.54 \%)$ were positive cows by PCR only (Table 2).

Table 2. Relationship between positive results of ELISA and PCR

\begin{tabular}{lccc}
\hline \hline Test & PCR & & \\
\hline ELISA & Positives & Negatives & Total \\
Positives & $11(8.46 \%)$ & $10(7.69 \%)$ & $21(16.15 \%)$ \\
Negatives & $2(1.54 \%)$ & 107 & $109(83.85 \%)$ \\
Total & $13(10 \%)$ & 117 & 130 \\
\hline
\end{tabular}

Regarding to clinical data, significant increases $(\mathrm{P}<0.05)$ in positive cows by both assays were reported in cows of $>5$ years of age, crossbred, infested with ticks, lived with sheep, and raised in a herd of $>25$ cattle. As well as a significant elevation $(\mathrm{P}<0.05)$ in positivity was detected in cows suffering from low milk production and abortion (Table 3).

Genomic DNAs for two PCR-positive samples of IS1111A transposase gene were analyzed phylogenetically, named as C. burnetii IQ-No.5 and C. burnetii IQ-No.6, and recorded in NCBI under an accession numbers of MN473204.1 and MN473205.1, respectively. Comparative analysis of IS1111A transposase nucleotides sequence of study samples with number of $C$. burnetii strains present in the GenBank database was constructed using the ClustalW Alignment of MEGA software. The results showed that there were nucleotide alignment similarities $(*)$ and substitution mutations in IS1111A transposase gene (Figure 3).

Comparative identity for genetic variations between the local strains and NCBI-BLAST strains/isolates was showed similarity of 97\%; whereas, the total genetic mutations/changes were 0.1-0.6\% (Figure 4, Table 4). 
Table 3. Association of clinical data to positive results of ELISA and PCR assay

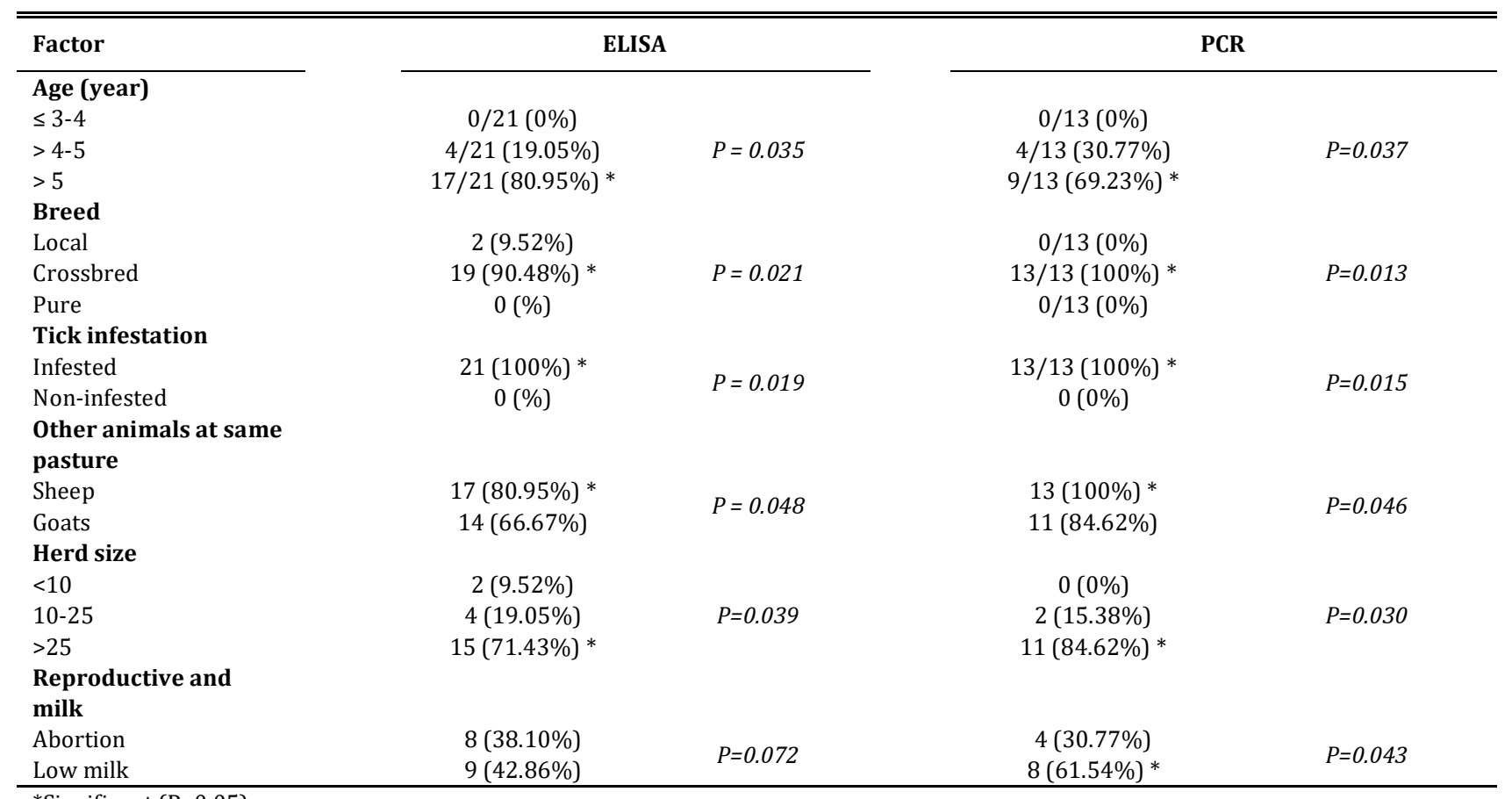

*Significant $(\mathrm{P}<0.05)$

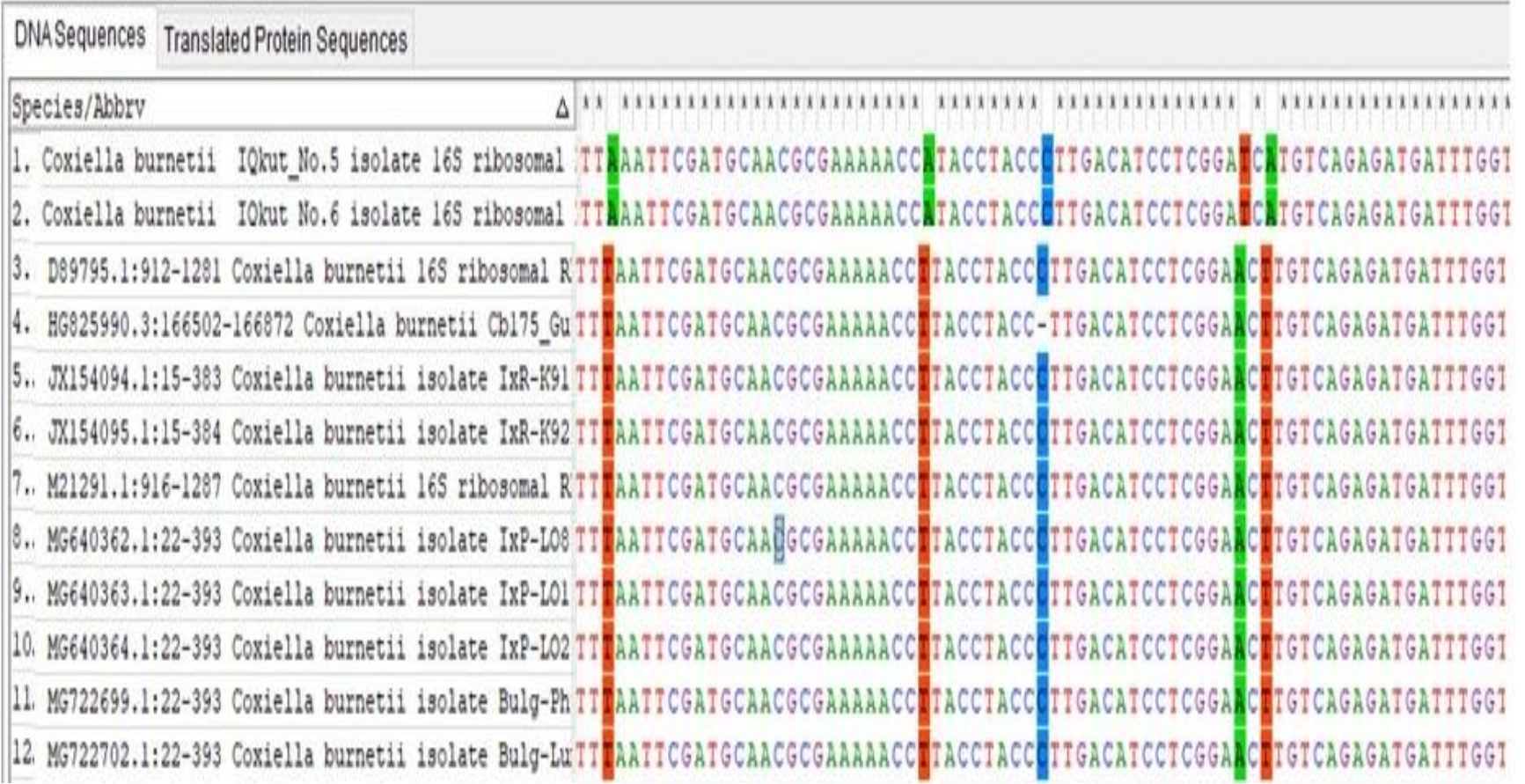

Figure 3. Multiple sequence alignment analysis similarity 


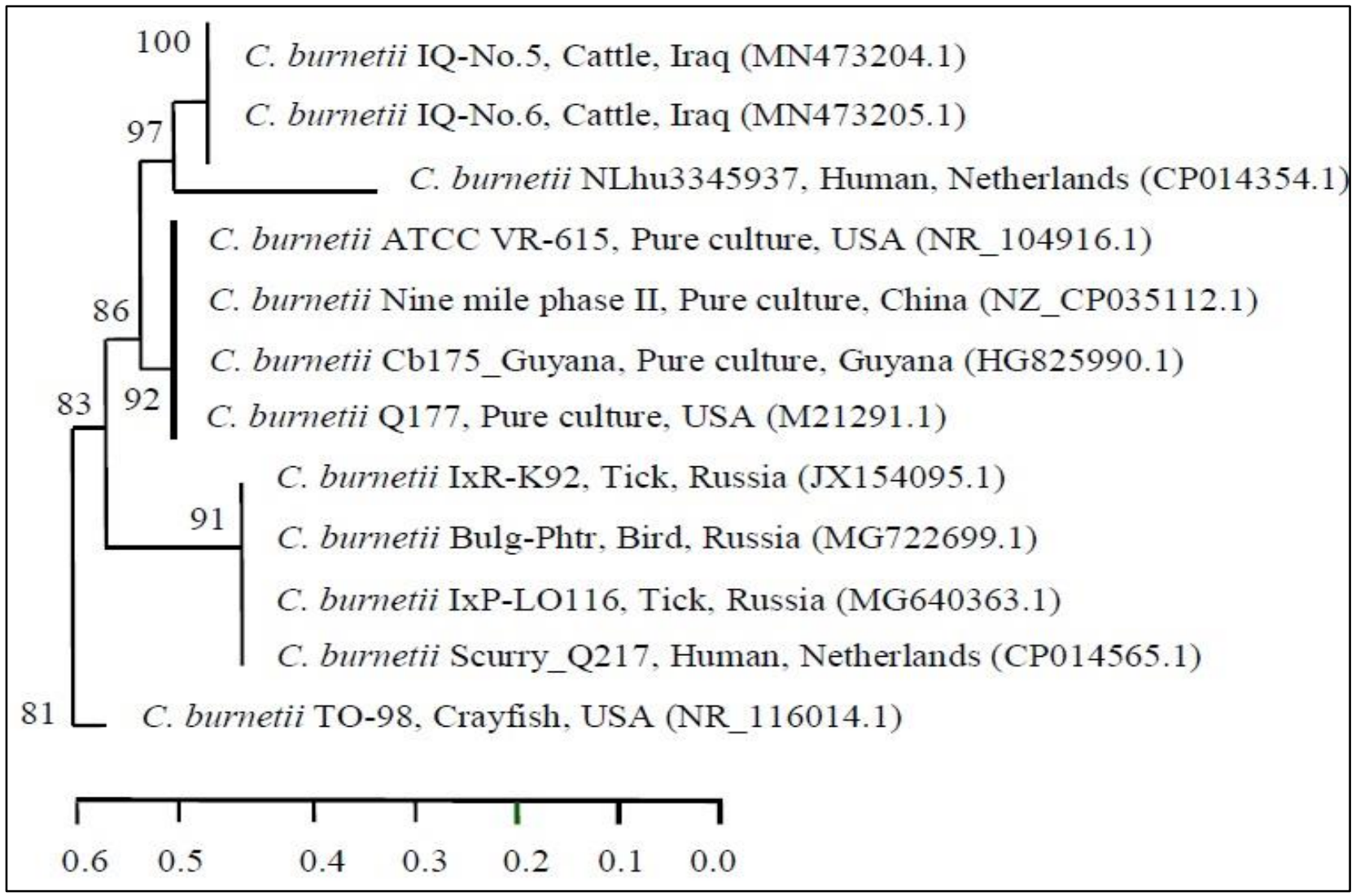

Figure 4. Phylogenetic tree analysis based on IS1111A transposase gene

Table 4. Phylogenetic tree analysis based on IS1111A transposase gene

\begin{tabular}{|c|c|c|c|}
\hline \multirow[b]{2}{*}{ Numbers } & \multirow[b]{2}{*}{ Country } & \multicolumn{2}{|c|}{ Identity (\%) } \\
\hline & & IQ-5 & IQ-6 \\
\hline Coxiella burnetii strain IQ-No.5 16S ribosomal RNA gene, partial sequence & Iraq & - & 100 \\
\hline Coxiella burnetii strain IQ-No.6 16S ribosomal RNA gene, partial sequence & Iraq & 100 & - \\
\hline Coxiella burnetii strain 3345937 sequence & Netherlands & 97.10 & 97.06 \\
\hline C. burnetii strain ATCC VR-615 16S ribosomal RNA, partial sequence & USA & 96.74 & 96.67 \\
\hline Coxiella burnetii strain nine mile phase II chromosome, complete genome & China & 96.74 & 96.63 \\
\hline Coxiella burnetii Cb175-Guyana, complete genome & Guyana & 96.74 & 96.64 \\
\hline Coxiella burnetii $16 \mathrm{~S}$ ribosomal RNA & USA & 96.74 & 96.68 \\
\hline Coxiella burnetii isolate IxR-K92 $16 \mathrm{~S}$ ribosomal RNA gene, partial sequence & Russia & 96.72 & 96.69 \\
\hline Coxiella burnetii isolate Bulg-Phtr $16 \mathrm{~S}$ ribosomal RNA gene, partial sequence & Russia & 96.44 & 96.43 \\
\hline $\begin{array}{l}\text { Coxiella burnetii isolate IxP-L0116 } 16 \mathrm{~S} \text { ribosomal RNA gene, partial } \\
\text { sequence }\end{array}$ & Russia & 96.44 & 96.43 \\
\hline Coxiella burnetii strain Scurry-Q217 chromosome & Netherlands & 96.44 & 96.42 \\
\hline Coxiella burnetii strain T0-9816S ribosomal RNA, partial sequence & USA & 94.33 & 94.32 \\
\hline
\end{tabular}

Table 5. NCBI-BLAST Homology Sequence identity (\%)

\begin{tabular}{|c|c|c|c|c|}
\hline \multirow[t]{2}{*}{ Strain } & \multirow[t]{2}{*}{ GenBank Accession No. } & \multicolumn{3}{|c|}{ NCBI-BLAST Homology Sequence } \\
\hline & & Isolate name & Accession No. & identity \\
\hline C. burnetii IQ-No.5 & MN473204.1 & C. burnetii 3345937 & СР014354.1 & $99.10 \%$ \\
\hline C. burnetii IQ-No.6 & MN473205.1 & C. burnetii 3345937 & СР014354.1 & $99.06 \%$ \\
\hline
\end{tabular}


NCBI-BLAST Homology Sequence recorded that there was a high significant identity $(\mathrm{P}<0.05)$ between the local, C. burnetii IQ-No.5 and C. burnetii IQ-No.6 strains and $C$. burnetii 3345937 (CP014354.1) of Netherlands isolates at $99.10 \%$ and $99.06 \%$ respectively (Table 5).

\section{DISCUSSION}

Coxiellosis in cattle herds is known to be widespread and enzootic (3). The diagnosis of $C$. burnetii infection in animals is of great importance not only to identify the infected herds/flocks but also to determine the risk of disease transmission to humans $(21,22)$. In Iraq, there is limited information about this organism in humans and livestock populations. In cattle, only one serological report was carried out previously (23). Serologically, ELISA finding of our study was higher than what was reported in Iraq (7.37\%), (23); and Albania (7.9\%), (24); compatible with that was recorded in Germany (14.8\%), (25); Australia (16.8\%), (26); and Egypt (19.3\%), (27); and lower than was observed in Iran (27.83\%), (28); and Turkey (29\%), (18). To the best of our knowledge, this is the first Iraqi molecular study performed to investigate the prevalence of bovine coxiellosis in lactating cows. In comparison to other studies, the finding of present study was higher than what it was reported in Turkey (1.42\%), (18); and Iran (6.2\%), (29); compatible with that was reported in Italy (11.9\%), (30); and lower than what it was confirmed in France (21.1\%), (11); and Netherland (56.6\%), (31).

Significant increases in positive findings of ELISA comparing to PCR were reported; and this could be because of presence of more chronic infections than acute cases due to a host or seasonal factors. Astobiza et al. (2012) detected that serological results should be further analyzed with caution, and that other complementary analysis needed to be done (32). Therefore, our results were in expectance since PCR was more sensitive and greatly specific than ELISA in detecting of $C$. burnetii $(33,34)$. There was a high possibility of false positive or negative ELISA can be resulted due to insufficient blocking of immobilized antigen, antibody instability, seroconversion, and crossreaction of the secondary antibody (35). For PCR, false negative results might be caused by many factors correlated with the type of tested sample, method for collection, preservation, and DNA extraction, type of PCR assay, targeted gene, and length of designed primers (36).

Among seropositive cows, a significant variation in levels of ODs, showed in this study, may represent different phases of infection among the studied animals. High values of OD indicated a recent chronic phase of disease; whereas lower values referred to either early acute phase of infection where there was limit development for IgG antibodies, or the terminal period of chronic phase of $C$. burnetii infection. Combination of ELISA and PCR in current study showed that a number of study cows were positives by both assays. It is suggested in this study that these animals are of great importance as they represent the source of potential risk to other animals, as well as, for their owners. In addition, combination of ELISA and PCR can be used as a gold standard method for more reliable detection of infections, and for increasing the sensitivity and specificity of diagnosis.

As shown in present study, positive percentage of ELISA and PCR were revealed a significant elevation in their values with increasing the age of a cow, crossbreed animals, tick infestation, presence of sheep at the same pasture, and cows within a herd size of $>25$ ones. Although several studies have identified the risk factors of infection in cattle, their respective quantitative contributions to the transmission or spreading of infection are still unknown $(37,38)$. Regarding to age, Seo et al. (2017) referred to that the early exposure and continues infection in addition to occupational or environmental influences, breeding may play a role in development of infection (39). In this study, it is suggested that diminishing immunity can occur along with increasing the age as a result concurrent different infection, and high level of stress particularly in cows due to large milk production and pregnancies. However, all these reasons might act together for increasing of susceptibility. Crossbreed study cows were showed a high positivity rather than local and pure breeds; and this might belong to that different breeds might have variation in genetic map which was reflected on their sensitivity or resistance to infection in addition to management factors that played a great role in controlling of a disease.

Although, ticks were not essential in the natural cycle of C. burnetii in livestock, they formed part of the transmission cycle of the organism from animals to animals and from animals to humans $(40,41)$. Mediannikov et al. (2010) reported that at least viable Coxiella might survive for a long time in ticks, particularly soft tick, and transmit of organism transovarially and transstadially, and may secret via feces, saliva, and coxal fluid (42). Pandit et al. (2016) found that among all the new herd infection, 925 were attributed to an airborne transmission and the rest to cattle trade (3).

Even though most of the recent human outbreaks were known to originate from small ruminants (sheep and goats), the considered role of these animals in transmission of infection to other domestic animals remained to be elucidated. In this study, the finding showed that there was a high positive rate of infected cows that lived and fed at the same pasture. Intensive cattle farming with high prevalence of infection could become a concern for public health. In this study, a large herd size was associated with $C$. burnetii positivity, consistent with other studies $(22,43)$.

Although there was no evidence for $C$. burnetii being associated with herd outbreaks of abortion in cattle, number of studies concluded that this organism was an infrequent cause of abortion in cattle $(44,45)$. In Iraq, brucellosis has been recognized as the main causes of 
decreased reproductive efficiency and abortions in cattle as well as in sheep $(46,47)$. For this reason, many abortion cases attributed to brucellosis might be largely correlated with coxiellosis. In a recent study, the authors showed that the prevalence of brucellosis in cattle was $0.97 \%$, while $3.23 \%$ of which were positives to Coxiella (49). Other study detected no positive results for B. Abortus, but a high prevalence for $C$. burnetii $(52.9 \%)$ was found in group of cattle (49). Low milk production detected in positive study cows was one of the most clinical signs that reported in cattle infected by brucellosis (50). These findings indicated that the clinical signs of reproductive pathogens might be shared leading to misdiagnosis of the real pathogenic cause.

In this study, phylogenetic analysis of local $C$. burnetii strains was revealed on a high relative identity with GenBank-NCBI Netherland strains/isolates NL3262 which originated from the largest Global human outbreak (51). These findings indicated that the local strains might be descended from the ancestor of Dutch strains/isolates and that certain factors might be played a role in distribution of the ancestor around the world such as moving of animals and humans in addition to importation and exportation processes.

The positive findings of present study demonstrated that the percentage of infected cows in Iraq is relatively high. ELISA and PCR can provide more reliable findings. Age, breed, ticks, sheep, and herd size as risk factors showed a significant association with bovine coxiellosis. Further assessment needs to be performed to ensure the correct identification and areas subjected to the increased risk of $C$. burnetii infections. Coxiella should also be listed as abortive pathogen. There is a high level of identity detected between the local $C$. burnetii strains reported in this study and GenBank-NCBI Dutch strains/isolates. Additional studies in other areas/herds are required to establish epidemiological database.

\section{ConTributions}

This work was part of $\mathrm{PhD}$ dissertation in the Department of Internal and Preventive Veterinary Medicine, University of Baghdad (Baghdad, Iraq). Hasanain A.J. Gharban was responsible on the work as a PhD student and Prof. Dr. Afaf Abdulrahman Yousif as the supervisor.

\section{ACKNOWLEDGEMENTS}

The authors would like to thank Prof. Dr. Hameed Ali Kadhim (Dean of the College of Veterinary Medicine, University of Baghdad) and Prof. Dr. Saleem Amin Hasso (Head of Department of Internal and Preventive Veterinary Medicine) for the completion this work.

\section{FUNDING}

Authors declare that above-submitted work was not funded by any governmental or private funding source nor supported by any financial projects.

\section{CONFLICT OF INTEREST}

The authors declare that there is no conflict of interest.

\section{REFERENCES}

1. Mori M, Mertens K, Cutler SJ, Santos AS. Critical aspects for detection of Coxiella burnetii. Vector Borne Zoonotic Dis. 2017; 17(1): 33-41.

2. Keshavamurthy R, Singh BB, Kalambhe DG, Aulakh RS, Dhand NK. Prevalence of Coxiella burnetii in cattle and buffalo populations in Punjab, India. Prev Vet Med. 2019; 166(1): 16-20.

3. Pandit P, Hoch T, Ezanno P, Beaudeau F, Vergu E. Spread of Coxiella burnetii between dairy cattle herds in an enzootic region: modelling contributions of airborne transmission and trade. Vet Res. 2016; 47(1): 1-16.

4. Lee KH, Lee HK, Baek KH, Oem JG, Kim HY. Abortion caused by Coxiella burnetii in a cow and oat in Korea. J Vet Sci Tech. 2018; 9(1): 1-3.

5. Mohammed OB, Jarelnabi AA, Aljumaah RS, Alshaikh MA, Bakhiet AO, Omer SA, Hussein MF. Coxiella burnetii, the causative agent of $Q$ fever in Saudi Arabia: molecular detection from camel and other domestic livestock. Asian Pac J Trop Med. 2014; 7(9): 715-9.

6. Courcoul A, Monod H, Nielen M, Klinkenberg D, Hogerwerf L, Beaudeau F, Vergu E. Modelling the effect of heterogeneity of shedding on the within herd Coxiella burnetii spread and identification of key parameters by sensitivity analysis. J Theor Biol. 2011; 284(1): 130-41.

7. De Biase D, Costagliola A, Del Piero F, Di Palo R, Coronati D, Galiero G, Raoult D. Coxiella burnetii in infertile dairy cattle with chronic endometritis. Vet Pathol. 2018; 55(4): 539-42.

8. Duron O, Noël V, Mccoy KD, Sidi-Boumedine K, Morel O, Arnathau C. The recent evolution of a maternally-inherited endosymbiont of ticks led to the emergence of the $\mathrm{Q}$ fever pathogen, Coxiella burnetii. PLoS Pathog. 2015; 11(5): 1-23.

9. Betancur CA, Rubio M, Barrera J, Bedoya JC. Seroprevalence of Coxiella burnetii in cattle farm workers in the department of Antioquia. Acta Med Colomb. 2015; 40(1): 20-3.

10. Barandika JF, Alvarez-Alonso R, Ja do I, Hurtado A, García-Pérez AL. Viable Coxiella burnetii in hard cheeses made with unpasteurized milk. Int J Food Microbiol. 2019; 303 (1): 42-5.

11. Guatteo R, Seegers H, Taurel AF, Joly A, Beaudeau F. Prevalence of Coxiella burnetii infection in domestic ruminants: a critical review. Vet Microbiol. 2011; 149(1-2): 1-16.

12. Melenotte C, Million M, Raoult D. New insights in Coxiella burnetii infection: diagnosis and therapeutic update. Expert Rev Anti Infect Ther. 2020; 18(1): 75-86.

13. Francis R, Mioulane M, Le Bideau M, Mati MC, Fournier PE, Raoult D, La Scola B. High Content Screening, a reliable system for Coxiella burnetii isolation from clinical samples. bioRxivorg. 2019; 4 (1): 134.

14. Anderson A, Bijlmer H, Fournier PE, Graves S, Hartzell J, Kersh GJ, Nicholson WL. Diagnosis and management of Q fever-United States, 2013: recommendations from CDC and the Q Fever Working Group. MMWR Recomm Rep. 2013; 62(3): 1-29.

15. Plummer PJ, McClure JT, Menzies P, Morley PS, Van den Brom R, Van Metre DC. Management of Coxiella burnetii infection in livestock populations and the associated zoonotic risk: A consensus statement. J Vet Intern Med. 2018; 32(5): 1481-94. 
16. Capuano F, Proroga YR, Mancusi A, Perugini AG, Berri M. Evaluation of DNA preparation methods combined with different PCR-based assays for Coxiella burnetii detection in milk. Large Anim Rev. 2016; 22 (1): 59-62.

17. Borji S, Jamshidi A, Khanzadi S, Razmyar J. Detection of Coxiella burnetii and sequencing the IS1111 gene fragment in bulk tank milk of dairy herds. Iran J Vet Sci Technol. 2015; 6(2): 21-8.

18. Saglam AG, Sahin M. Coxiella burnetii in samples from cattle herds and sheep flocks in the Kars region of Turkey. Vet Med. 2016; 61 (1): 17-22.

19. George D, Mallery P. SPSS $®$ for Windows $₫$ step by step: A simple guide and reference. 4th ed. Boston: Allyn and Bacon; 2003. P. 3579 .

20. Neyeloff JL, Fuchs SC, Moreira LB. Meta-analyses and Forest plots using a microsoft excel spreadsheet: step-by-step guide focusing on descriptive data analysis. BMC Res Notes. 2012; 5(1), 1-6.

21. Knobel DL, Maina AN, Cutler SJ, Ogola E, Feikin DR, Junghae M, Njenga MK. Coxiella burnetii in humans, domestic ruminants, and ticks in rural western Kenya. The Am J Trop Med Hyg. 2013; 88(3): 513-8.

22. Schimmer B, Schotten N, Van Engelen E, Schneeberger PM, Van Duijnhoven YTHP. Coxiella burnetii seroprevalence and risk for humans on dairy cattle farms, the Netherlands, 2010-2011. Emerg Infect Dis. 2014; 20(3): 417-25.

23. Abed J, Salih AA, Abd-ul-husien A. Seroprevalence Coxiella burnetii among cows and sheep in Thi-Qar Province/Iraq. Al-Qadisiyah J Vet Med Sci. 2010; 9(2): 26-30.

24. Çekani M, Papa A, Kota M, Velo E, Berxholi K. Report of a serological study of Coxiella burnetii in domestic animals in Albania. Vet J. 2008; 175(2): 276-8.

25. Böttcher J, Vossen A, Janowetz B, Gangl A, Randt A, Meier N. Insights into the dynamics of endemic Coxiella burnetii infection in cattle by application of phase-specific ELISAs in an infected dairy herd. Vet Microbiol. 2011; 151(3-4): 291-300.

26. Cooper A, Hedlefs R, McGowan M, Ketheesan N, Govan B. Serological evidence of Coxiella burnetii infection in beef cattle in Queensland. Aust Vet J. 2011; 89(7), 260-4.

27. Klemmer J, Njeru J, Emam A, El-Sayed A, Moawad AA, Henning K, El-Diasty MM. Q fever in Egypt: Epidemiological survey of Coxiella burnetii specific antibodies in cattle, buffaloes, sheep, goats and camels. PloS ONE. 2018; 13(2): 1-12.

28. Esmaeili S, Pourhossein B, Gouya MM, Amiri FB, Mostafavi E. Seroepidemiological survey of $Q$ fever and brucellosis in Kurdistan Province, western Iran. Vector Borne Zoonotic Dis. 2014; 14(1): 41-5.

29. Rahimi E, Doosti A, Ameri M, Kabiri E, Sharifian B. Detection of Coxiella burnetii by nested PCR in bulk milk samples from dairy bovine, ovine, and caprine herds in Iran. Zoonoses Public Health. 2010; 57(7-8): e38-e41.

30. Parisi A, Fraccalvieri R, Cafiero M, Miccolupo A, Padalino I, Montagna C, Sottili R. Diagnosis of Coxiella burnetii-related abortion in Italian domestic ruminants using single-tube nested PCR. Vet Microbiol. 2006; 118(1-2): 101-6.

31. Muskens J, Van Engelen E, Van Maanen C, Bartels C, Lam TM. Prevalence of Coxiella burnetii infection in Dutch dairy herds based on testing bulk tank milk and individual samples by PCR and ELISA. Vet Rec. 2011; 168 (1): 79-84.

32. Astobiza I, Ruiz-Fons F, Pinero A, Barandika JF, Hurtado A, GarciaPerez AL. Estimation of Coxiella burnetii prevalence in dairy cattle in intensive systems by serological and molecular analyses of bulktank milk samples. J Dairy Sci. 2012; 95(4): 1632-8.

33. Kargar M, Rashidi A, Doosti A, Najafi A, Ghorbani-Dalini S. The sensitivity of the PCR method for detection of Coxiella burnetii in the milk samples. Zahedan J Res Med Sci. 2015; 17(6): e988-e992.
34. Marushchak LV, Deriabin ON, Dedok L, Volosyanko E, Garcavenko T. Development of a PCR Kit for Detection of Coxiella burnetii in Ukraine. Vector Borne Zoonotic Dis. 2019; 20 (2): 100-6.

35. Sakamoto S, Putalun W, Vimolmangkang S, Phoolcharoen W, Shoyama Y, Tanaka H, Morimoto S. Enzyme-linked immunosorbent assay for the quantitative/qualitative analysis. J Nat Med. 2018; 72(1): 32-42.

36. Garibyan L, Avashia N. Research techniques made simple: polymerase chain reaction (PCR). J Investig Dermatol. 2013; 133(3): e1-e8.

37. Nusinovici S, Hoch T, Widgren S, Joly A, Lindberg A, Beaudeau F. Relative contributions of neighbourhood and animal movements to Coxiella burnetii infection in dairy cattle herds. Geospat Health. 2013; 8(2): 471-7.

38. Van den Brom R, Van Engelen E, Vos J, Moll L, Roest HJ, Vellema P. Detection of Coxiella burnetii in the bulk tank milk from a farm with vaccinated goats, by using a specific PCR technique. Small Rumin Res. 2013; 110 (2-3): 150-4.

39. Seo MG, Ouh IO, Lee SH, Kim JW, Rhee MH, Kwon OD, Kwak D. Prevalence of Coxiella burnetii in cattle at South Korean national breeding stock farms. PloS ONE. 2017; 12(5): 1-10.

40. Khoo JJ, Lim FS, Chen F, Phoon WH, Khor CS, Pike BL, AbuBakar S. Coxiella detection in ticks from wildlife and livestock in Malaysia. Vector Borne Zoonotic Dis. 2016; 16(12): 744-51.

41. Knap N, Žele D, Biškup UG, Avšič-Županc T, Vengušt G. The prevalence of Coxiella burnetii in ticks and animals in Slovenia. BMC Vet Res. 2019; 15(1): 368-73.

42. Mediannikov O, Fenollar F, Socolovschi, C, Diatta G, Bassene H, Molez JF, Raoult D. Coxiella burnetii in hmans and ticks in rural Senegal. PLoS Negl Trop Dis. 2010; 4(4): 654-61.

43. Park JH, Chu H, Yoo SJ, Hwang KJ, Lim HS. Serologic survey and risk factors for Coxiella burnetii infection among dairy cattle farmers in Korea. J Korean Med Sci. 2018; 33(39): 245-54.

44. Jensen TK, Montgomery DL, Jaeger PT, Lindhardt T, Agerholm JS, Bille-Hansen VI, Boye M. Application of fluorescent in situ hybridisation for demonstration of Coxiella burnetii in placentas from ruminant abortions. APMIS. 2007; 115(4): 347-53.

45. Muskens J, Wouda W, von Bannisseht-Wijsmuller T, Van Maanen C. Prevalence of Coxiella burnetii infections in aborted fetuses and stillborn calves. Vet Rec. 2012; 170(10): 260-6.

46. Ahmme MA, Amen AM, Ghaffar NM, Omar LT. Seroprevalence of cattle brucellosis by rosebengal and ELISA tests in different villages of Duhok province. Iraqi J Vet Med. 2011; 35(1): 71-5.

47. Al-Tae AH, Al-Samarrae EA. Detection of Brucella antibodies of sheep in Al-Anbar province by using some serological tests. Iraqi J Vet Med. 2013; 37(1): 7-12.

48. Ghasemi A, Hajinezhad MR, Esmaeili S, Mostafavi E. Seroprevalence of Q Fever and Brucellosis in Domestic and Imported Cattle of Southeastern Iran. J Med Microbiol Infect Dis. 2018; 6(2): 48-52.

49. Changoluisa D, Rivera-Olivero IA, Echeverria G, Garcia-Bereguiain MA, de Waard JH. Serology for Neosporosis, Q fever and Brucellosis to assess the cause of abortion in two dairy cattle herds in Ecuador. BMC Vet Res. 2019; 15(1): 194-9.

50. Lindahl-Rajala E, Hoffman T, Fretin D, Godfroid J, Sattorov N, Boqvist S, Magnusson U. Detection and characterization of Brucella spp. in bovine milk in small-scale urban and peri-urban farming in Tajikistan. PLoS Negl Trop Dis. 2017; 11(3): 1-12.

51. Kuley R, Smith HE, Janse I, Harders FL, Baas F, Schijlen E, Bossers A. First complete genome sequence of the Dutch veterinary Coxiella burnetii strain NL3262, originating from the largest global Q fever outbreak, and draft genome sequence of its epidemiologically linked chronic human isolate NLhu3345937. Genome Announc. 2016; 4(2): e5-e16. 


\section{التحري المصلي والجزيـــي الجينـي للكوكسيـلا بورنيتـي في الأبــــار المُّدرة للحليب، العراق \\ حنين عبد الحسين جعفر غربان وعفاف عبد الرحمن يوسف \\ فرع الطب الباطني و الوقائي البيطري، كلية الطب البيطري، جامعة بغداد، بغداد، العراق \\ الخـلاصــة}

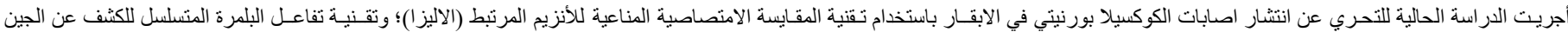

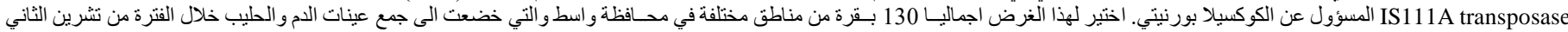

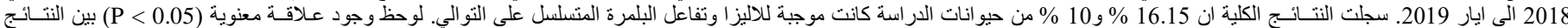

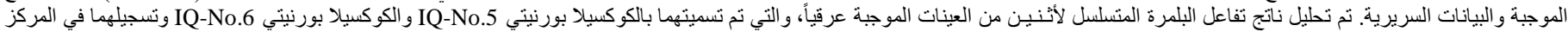

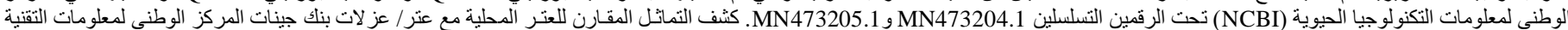

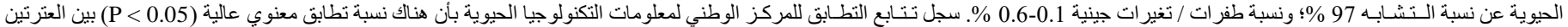
المحليتين؛ الكوكسيلا بورنيتي

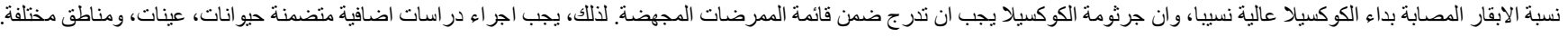

